\title{
El Concepto de Interculturalismo en un Mundo Complejo
}

The Concept of Interculturalism in a Complex World

\author{
Dr. Pablo Fernando Sarzosa Játiva \\ Investigador Juridico, Cardinal Abogados y Docente de la UCE
}

Artículo Original (Invesigación)

RFJ, No. 1, 2017, pp. 175-185, ISSN 2588-0837

RESUMEN: La interculturalidad implica la existencia de una diversidad cultural con potencial para actuar colectivamente a través de una cobertura simbólica, que imprime un cierto grado de cohesión y permanencia histórica, legitimando cualquier acción estratégica trazada por los grupos. Este análisis se da dentro de un argumento del espacio intersubjetivo en el que los fundamentos de la identidad colectiva se encontrarían en las sociedades modernas, donde las funciones cohesivas simbólicas y las posibles interacciones situacionales y contextuales reproducen los grupos culturales dentro de una integración lógica de espacios. Todo el bagaje de encuentros y desacuerdos culturales influye en la construcción de la identidad, dentro de la lógica de estructuras y significados institucionalizados, dentro de una dinámica de reproducción social. La discusión en este documento integra un enfoque histórico de este Proyecto Inacabado en Ecuador, en la Comunidad Andina en América Latina.

PALABRAS CLAVE: Interculturalidad, diversidad cultural, identidad colectiva, grupos culturales, identidad.

ABSTRACT: Interculturalism implies the existence of a cultural diversity with potential to act collectively through a symbolic coverage, which prints a degree of cohesion and historical permanence, legitimizing any strategic action traced by groups. This analysis is given within an argument from intersubjectivity space in which the foundations of collective identity would be found in modern societies, in which the symbolic cohesive functions and potential situational and contextual interactions, reproduce culture groups within a logical integration of spaces. All the baggage of cultural encounters 
and disagreements influences the construction of identity, within the logic of institutionalized structures and meanings, within a dynamic of social reproduction. The discussion in this paper integrates a historical approach from this Unfinished Project in Ecuador, in the Andean Community in Latin America.

KEYWORDS: Interculturality, cultural diversity, collective identity, cultural groups, identity.

\section{INTRODUCTION}

The idea of Interculturalism has presented hitherto more commonly in the Latin American discussion of diversity in the arena of political issues, mainly since the 1990 s. In this paper, I present a working model for analysing collective identity which integrates a historic approach as a major strand in the discovery of the potential of Interculturalism, from the Unfinished Project of the Ecuadorian case, in the Andean Community in Latin America.

This choice is motivated by an understanding of Interculturalism as a as a broader form of knowledge sharing and a tool of the process of strengthening the identity of the human being, who seek the canalization of their diversity and social conflict, within a framework of collective identification with other sectors of society, to promote communal identity development inspired by the cultural values, even as a space for social movement alliances.

The first section is dedicated to elaborating on the notion of Interculturalism as space of conflict, within the Andean historical context, as a strategy of social actors framed in subalterity, in seeking the adoption of their aspirations by the universalist culture in the various fields in which these tactics have been used by intercultural dialogue. The second section is dedicated to the discussion of the potential of Interculturalism, as a lived experience and as a chance to reach the rational understanding between the citizens of a more encompassing identity, and to sketching the implications that this analysis has within the intersubjectivity logic in which the foundations of collective identity would be found in modern societies. 


\section{INTERCULTURAL CONFLICT IN THE ANDEAN PLURI- CULTURAL SOCIETIES}

In today's multicultural Andean context, more than any other space, Globalization has not been a homogeneous phenomenon, on the contrary, in these societies have increased the tensions that provoke this process. One of these tensions, is the one between the trend towards standardization and the resurgence of the particular: the tension between the global and the local. [Degregori, 1998, 34.]

Thus we find that in our andean states, nation-state projects, are besieged from above by globalization and its models economic and political factors that lead to the end of national borders and entry into the era of post-national states, and from below by the emergence of ethnic and cultural movements, that accentuate their difference and undertaking a series of policies to order to achieve sovereign right to exercise its Culture and to redefine public spaces.

In the next lines we will sketch the historic background to analysing the Intercultural conflict in Andean's pluricultural societies; but first, however, let us say that the conceptual framework of Interculturalism, on which we will work, is the conflict space alliances of social movements, and identity strategies and citizen participation as Subaltern ${ }^{35}$ social actors, in the pursuit of making their aspirations by universalist political culture, seeking diversity and processing of existing social conflict.

The discussion of cultural conflict in Latin America convokes to a approach to the colonial Lifeworld ${ }^{36}$, which would mean a trip without return for all the people, even for multiple spanish and portuguese identities who arrived with the idea of a separatist duality, which failed from the begining, when the relational logic caused a borderless coexistence between the various contingents present in this new world.

35 The terms referring to Subaltern or Subalteridad understood within the critical reflection on the negation of the Other and his alterity, their practices and legitimate knowledge; in other words, linked to ideas of Otherness, that won position in the private and public spaces in Latin America to disrupt the old perceptions.

36 The term Lifeworld (German: Lebenswelt), understood as horizon in which the communicative agents move, has been taken from Jürgen Habermas (1993. 161). 
For Native Americans, Africans and Europeans, the project of modernity present in the collective imaginary throughout the colonial period, mean a transformation in the Lifeworld as a result of establishment of a number of strategies in the different Fields ${ }^{37}$ Fields and by the various social actors, and of the deployment of power's game within an initial Field-of-force ${ }^{38}$ that seemed not limit to dominant groups in seeking legitimation through racist ideologies, and discrimination, which in the Colonial America in the Andes would be built on a potent mix of ethnicity, class, gender, mostly on the indigenous cultures.

And the Latin American emergency as this life category, which embraces the actual presence in the historical processes of certain human groups that have been marginalized, will continue after the colonial period, through a post-colonial stage that has not stopped, but that forced the State ${ }^{39}$ to perform a hegemonic policy, most closely associated with the concept of Gramsci. ${ }^{40}$

And this hegemonic policy is framed by the second half of the XIX century, within the indigenist policy, impulsed by the liberal movement ${ }^{41}$ and maintained in populations of indigenous America until the late 1970s, when consistent allegations become stronger by those affected, against these strategies integrationists and acculturationalists.

Indeed, indigenist policy, which appears in the XIX century promoted by Liberals, as the "legitimate" complainants of the continental conservatism and of the feudal sectors, was an initiative

37 The term Field (French: champ), refers to a structured system of objective forces that can be imposed on all agents that penetrate it, and simultaneously a space of conflict and competition (Pierre Bourdieu, 1995. 63).

38 The term Field-of-force, in the idea that the dominant groups must make certain concessions to groups dominated in relationships, is taken from Edward P. Thompson (Thompson, 1979. 131).

39 The term "State" in this paper will refer to the set of hegemonic groups with decision-making capacity, within the Latin American societies.

40 Applied not only in relation to social class, but also in terms of ethnicity and gender, as a political rather than cultural concept, where the dominant group has to dominate and lead other social groups by interpreting their aspirations, whereby the dominant group is also limited with your own project.

41 As acculturation response on indigenous peoples, promoted in the past two centuries by the Liberals, as the great whistleblower of the continental conservatism and of the feudal sectors. 
of non-indigenous sectors affected by a problem whose solution lay in the transformation of the servants into workers, cutting with their attachment to the feudal sectors, which certainly allowed many of them reach a range of development, but at the cost of a acculturational policy.

But a whole new discourse appears in indigenist policy, in the VIII Inter-American Indian Congress of Mérida, inaugurated by President Lopez Portillo in 1980, which is the result of the development of the indigenous organization in the region and provides a break up regarding to the national populist vision, with which was always handled this issue, by the political parties, who sought integration and acculturation of these nationalities.

This unprecedented speech, that suggested taking into account the indigenous's independent and autonomous organization, for actions as may be agreed in the future within the Inter-American Indian Congress, will clash with the policies of Nation-states, even when they adapt their strategies again in order to legitimizing their systems.

Let us briefly review the criticisms of indigenous policy in the 1970 s, many of which served as background to the conclusions of the VIII Inter-American Indian Congress of Mérida, among others: complaints of the integration policy; complaints of acculturationist policy; complaints of the colonization policy; rejection of indigenist policy to serve the dominant ideology; and, complaints of paternalism and lack of participation of the indigenous people in solving the problems that concern them (Marie-Chantal, 1985, 92 ).

This refusal to indigenist policy, will allow the preparation of indigenous intellectuals, self-aware, and aware of their confrontation with the State dominant culture.

The result is the creation of a new social agent that starts the early 1970s with identity strategies and the birth of a cultural and political movement that begin with demand of the recognition of certain collective rights.

The VIII Inter-American Indian Congress of Mérida, which, as was mentioned, provides a historical break with paternalism of indigenist policy in the early 1980s, will facilitate in the 1990s, the emergence of new social actors that constitute themselves in relevant forces, evidencing the crisis of limited political democracy. 
Indeed, in Ecuador, the Latin American indigenous movement will impulse unthinkable claims in that historical period: a reinterpretation of the story from the indigenous point of view, articulated with demands of autonomy, self-government and self-determination, that will present a new scenario with original practices of social struggle:

el levantamiento nacional y, luego, los levantamientos regionales; (forzando) al estado a una práctica política imprevista, cargada de simbolismos recién forjados y de connotación expansiva en el sistema político: al llamado diálogo, a la negociación directa entre ciudadanos distintos que exigen un reconocimiento colectivoétnico (como pueblos) y la cúpula del gobierno de los ciudadanos blanco-mestizos ${ }^{42}$ (Guerrero, 1983, 100).

By 1991, the indigenous nationalities in Ecuador had clearly defined policies for the government: constitutional reforms that recognize the country like Plurinational, and that allow to build a new political legal framework that covers the new collective rights of the indigenous people (Macas, 1991, 11).

Henceforth, the unpredictability of the potentialities of indigenous nationalities, or the development of their likely expectations by the state as the main social mechanism to reduce the predictability of the others, will be handled from the ascend of Subaltern cultures in the political field, and the development of new strategies and goals due to the new position reached by the indigenous people.

\section{NEGENTROPY AND ETHNICITY AS INDIGENOUS STRATEGY}

Indeed, after five hundred years of colonial and post-colonial resistance, the indigenous movement, strengthened through a collective identity construction, around ethnicity category, prompted a series of demands on the legal system, that ended with the fall of the

42 Local and regional uprising forcing the state to unforeseen political practice, loaded of newly forged symbolism and expansive connotation in political system: the socalled dialogue, direct negotiation between different citizens, demanding a cultural or collective identity recognition, and the government of citizens white-mestizos. 
constitutional legal barriers of the Nation-State in the late 1990s (von Hildebrand, 1996, 1-3).

But, what was the strategy adopted by indigenous peoples?.

Resistance, civil disobedience and appropriation of legal fissures in a first period, that coincide with the official indigenist policy of Nation-State, whose universalistic and positivistic culture, do not admitte cracks in the forecast of behaviors, and that consider the indigenous people in transit to national citizenship, after his adaptation to the West.

Identity and social identification Strategies, framed in Subalternity, as a reivindicative practice to the recognition of the pluricultural nature of countries, in a second period, in which the Nation-States were forced to make constitutional reforms, that "discovered" the existence of subaltern cultures with a range of social and collective rights.

Further, it is interesting to note that in this region the phenomenon of globalization produced not just a cultural entropy: a superculture of modernity that sought to dominate the traditional cultural formation, involving the siege vertically up to down (Sánchez, 1997, 65-98), but also a cultural negentropy, as a result of the tensions of this phenomenon: the emphasis of the difference, implying the siege vertically bottom to top (Degregori, 1998, 34).

In this context, the cultural movements adapted their identity strategy with these natural defense mechanisms that strengthen those cultural identity patterns more rooted in tradition, not just deepening their ethnic difference, but also producing new cultural territorialities, throught discourse adscription practices, leading in particular historical moment to the formation of a collective in Ecuador based on ethnic identification.

We are talking here, about the formation of interests via ethnicity identification, through interactions historically possible; in which, the symbolic while it is important, however cedes space to communicative action in the Intersubjectivity ${ }^{43}$, under the Habermasian approach, that

43 The term Intersubjectivity understood as a space for dialogue between the social partners that incentive cultural reproduction, has taken from Habermas (1988. 93). 
configures the rational formation of the collective will, cementing cultural identity in modern states due to its cohesive rol.

It is a cultural identification, as a permanent and sometimes conflicting construction, framed within an Identity strategy, in which can be emphasize certain cultural patterns by significant for a greater collective, at some historical point (Mercado Maldonado y Hernández, 2010, 243 - 244).

Indeed, as cultural Identity, the internalized set of cultural repertoires (cultural values) serves to the social actors, for creating new cultural territorialities within a historically specific space and socially structured (Giménez, 2000, 27), implying the existence of a Pluri-Identity Groups with potential to act against "others" through a symbolic coverage that gives it a degree of cohesion and historical permanence, legitimizing any strategic action traced by the group.

The Interactions of the Pluri-Identity Groups, in this context, are understood as a space of cooperative's behaviors reproduction, increase the emergency of the community's feelings through its contingent repetition, acting within the logic of the communication structures of modernity.

Finally, we must highlight the importance that has, within the discussion of intersubjectivity, assumed as a space for dialogue between social actors which stimulates cultural reproduction (interests and identities), the habermasian consensus.

Only in and through communicative action can the energies of social solidarity attached to religious symbolism branch out and be imparted, in the form of moral authority, both to institutions and to persons (Habermas, 1984, 61).

This Identity strategies via ethnicity identification requires seeking consensus, other than that achieved with the majority rule, of western dye, but reached by deliverations of equals, legitimizing the Collective. 


\section{CONCLUSIONS}

That the identity strategy of ethnic and cultural movements, is the result of a centripetal dynamic toward search for mechanisms of natural protection, does not imply that they are only manifestations of habitus and cultural reproductions, but also, actions in the territorial field on basis of a conscious choice of collective action, whose objective is the access to resources for creating the social change. At this point, the construction of a collective identity may play a central role to bringing legitimacy to strategic action.

Indeed, ethnic revitalization post-indigenist implied at least in the 1990s, a rebellion against the system, reivindication that at certain times it has not been only property of an ethnic group, but of gender, culture, class and so many other identities; reached, the Collective a temporary identity enough to access the spaces for dialogue of dominant groups and to to confront them, even though, only temporarily.

That's why we also understand the historical process of Interculturalism in Latin American as a project of institutionalization of the Interculturalism via the conformation of a space of alliances of the new social movements interested in a social movement wide.

These identities in the new post-national societies grouped around an ethnic identification on the basis of intercultural discourse, acquire central importance in the current debate on the future of our andean societies, in which indigenous cultures, no longer seem dispensable, and come to occupy a crucial site due to their past interactions that offer new possibles scenarios.

Finally, we must emphasize that this discussion we have handled from intersubjectivity space, in which the foundations of collective identity would be found in modern societies, in which symbolic role while it is important, however cedes space to the interactions historically possible, reproduced by culture's Group. 


\section{REFERENCES}

Barre, M-C. (1985). Ideologías Indigenistas y Movimientos Indios. México: Siglo XXI editores.

Baud, M. et all (1996). Etnicidad como estrategia en América Latina y El Caribe. Quito: Ediciones Abya-Yala.

Bourdieu, P. (1990). Sociología y cultura (Martha Pou trad.). México: Editorial Grijalbo, S. A. (Questions de sociologie. Les editions de Minuit, París, 1984).

Bourdieu, P. (1995). Respuestas por una antropología reflexiva. (Thomas Kauf trad.) Barcelona: Editorial Angrama S.A.

Degregori, C. I. (1993). Identidad étnica, movimientos sociales y participación política en el Perú. Democracia, etnicidad y violencia política en los países andinos [Alberto Adrianzén et al). Lima, Serie América Problema, num. 16, IEP/EFEA.

Giménez, G. (2000). Identidades en globalización. Espiral, Estudios sobre Estado y Sociedad, Vol. 7, No 19, Sep.-Dec.

Guerrero, A. (1983). Hacienda, capital y lucha de clases andina. Quito: Editorial El Conejo.

Habermas, J. (1984). The Theory of Communicative Action. II vols. Trad. Thomas McCarthy. Boston: Beacon.

Habermas, J. (1988). La Teoría de la Acción Comunicativa. Madrid: Ed. Taurus.

Habermas, J. (1993). Teoría de la Acción Comunicativa, complementos y estudios previos. México: Red Editorial Iberoamericana.

Macas, L. (1991). El levantamiento indígena visto por sus protagonistas. Quito: Amauta Rupacunapac Yachai-Instituto Científico de Culturas Indígenas.

Mercado Maldonado, A. y, Hernández Oliva A. (2010). El proceso de construcción de la identidad colectiva. Convergencia, Revista de 
Ciencias Sociales, num. 53, 2010, México: Universidad Autónoma del Estado de México.

Sánchez Parga, J. (1997). Globalización, Gobernabilidad y Cultura. Quito: Ediciones Abya-Yala.

Von Hildebrand, M. (1996). Entre la ley y la costumbre, in Derechos de los pueblos indígenas en las Constituciones de América Latina, (Enrique Sánchez Comp.). Colombia: Disloque editores.

Recibido: $15 / 02 / 2017$

Aprobado para publicación: 27/05/2017

Pablo Fernando Sarzosa Játiva: Master's degree in Asian Studies, Tamkang University (TKU Taiwán). Master's degree in Latin American Studies, Andean University "Simon Bolivar" (Andean Community). Master's degree in Social Project Design and Management, ESPOL Polytechnic University (Ecuador).

Correo electrónico: psarzosa@cardinalabogados.com 